\title{
PENGARUH MODEL PEMBELAJARAN TALKING STICK BERBANTUAN MEDIA QUESTION BOX TERHADAP HASIL BELAJAR IPA KELAS V
}

\author{
I.G.A.P. Anggi Seika Ayuni, Nym. Kusmariyatni, I Gst. Ngurah Japa \\ Program Studi Pendidikan Guru Sekolah Dasar, Univeritas Pendidikan Ganesha \\ E-mail:anggi_seika@yahoo.com,nym_kusmariyatni@yahoo.co.id,ngrjapa_pgsd@yahoo.co.id
}

\begin{abstract}
Abstrak
Penelitian ini bertujuan untuk mengetahui perbedaan hasil belajar antara kelompok siswa yang dibelajarkan dengan menggunakan model pembelajaran kooperatif tipe Talking Stick berbantuan media question box dan kelompok siswa yang dibelajarkan bukan dengan model pembelajaran kooperatif tipe Talking Stick berbantuan media question box pada siswa kelas V SD Gugus V Kecamatan Melaya Kabupaten Jembrana tahun pelajaran 2016/2017. Jenis penelitian ini adalah penelitian semu dengan rancangan non equivalen post test only control group design. Populasi penelitian ini adalah kelompok siswa kelas V SD Gugus V Kecamatan Melaya Kabupaten Jembrana tahun pelajaran 2016/2017 yang berjumlah 120 siswa. Sampel penelitian adalah siswa kelas V SDN 1 Tukadaya dan SDN 2 Tukadaya yang dipilih dengan teknik random sampling. Metode pengumpulan data dalam penelitian ini menggunakan metode tes. Instrumen yang digunakan berbentuk instrumen pilihan ganda (objektif). Data yang dikumpulkan dianalisis menggunakan analisis statistik deskriptif dan uji t. Hasil penelitian menunjukkan bahwa terdapat perbedaan yang signifikan pada hasil belajar IPA antara kelompok siswa yang dibelajarkan dengan menggunakan model pembelajaran kooperatif tipe talking stick berbantuan media question box dan kelompok siswa yang dibelajarkan bukan dengan model pembelajaran kooperatif tipe talking stick berbantuan media question box (thitung $=6,3>\mathrm{t}_{\text {tabel }}=2,009$ ). Dibuktikan pula oleh perbedaan skor rata-rata kelompok eksperimen yaitu 22,57 dan kelompok kontrol yaitu 15,64. Hal ini berarti model pembelajaran kooperatif tipe talking stick berbantuan media question box berpengaruh positif terhadap hasil belajar IPA siswa siswa kelas V SD Gugus V Kecamatan Melaya Kabupaten Jembrana tahun pelajaran 2016/2017.
\end{abstract}

Kata kunci : hasil belajar, IPA, talking stick

\begin{abstract}
This study were aiming to determine the differences in learning outcomes between group of students who were taught by using cooperative learning model Talking Stick type assisted by media question box and group of students who were not taught with cooperative learning model Talking Stick type assisted by media question box on students of grade V SD Gugus V Subdistrict Melaya Jembrana District on 2016/2017. The type of this research is a quasi research which design by non equivalent post test only control group design. The population of this study was a group of students of a grade V SD Gugus V Subdistrict Melaya, Jembrana District on 2016/2017 which amounted to 120 students. The samples of this research were the students of grade V SDN 1 Tukadaya and SDN 2 Tukadaya which was selected by random sampling technique. The data collection methods used in this study was a test method. The used instrument was a multiple choice instrument (objective). The collected data were analyzed by using descriptive statistical analysis and test. The results show that there are significant differences in the results of science learning between groups of students who were taught by using cooperative learning model of talking stick type assist by media question box and group of students who were not taught with cooperative learning model of talking stick type assist by question box ( $\mathrm{t}$ count $=6,3>t$ table $=2,009$ ). The results is proving by the average score differences of the experimental group is 22,57 and the control group is 15,64 . This means that cooperative learning model of talking stick type with media aid question box has a positive effect on science learning outcomes of students of grade V SD Gugus V Subdistrict Melaya Jembrana District on 2016/2017.
\end{abstract}

Keywords: learning outcomes, Sciences, talking stick

\section{Pendahuluan}

Sekolah dasar merupakan jenjang pendidikan dasar dalam pendidikan formal di Indonesia. Sekolah dasar memiliki andil besar dalam membangun pondasi pengetahuan untuk kelanjutan pendidikan ke jenjang selanjutnya. Dalam hal ini, sekolah dasar merupakan pusat pengembangan sikap, pengetahuan, dan keterampilan dasar yang nantinya dijadikan sebagai bekal untuk menuju pendidikan yang lebih tinggi. Pengembangan pengetahuan, keterampilan, dan sikap ini diajarkan melalui berbagai mata pelajaran dasar. Berdasarkan UndangUndang No. 20 Tahun 2003 pada Pasal 37 ayat 1 diketahui bahwa, salah satu mata pelajaran yang ada di sekolah dasar yang merupakan wahana untuk membekali siswa dengan pengetahuan, keterampilan, dan sikap yaitu mata pelajaran IPA.

Mata pelajaran IPA merupakan mata pelajaran yang mengajarkan tentang gejala alam yang berkaitan dengan kehidupan manusia. Mata pelajaran IPA di sekolah dasar selain merupakan wahana untuk membekali siswa dengan pengetahuan, keterampilan, dan sikap untuk melanjutkan ke jenjang pendidikan yang lebih tinggi juga sebagai sarana bagi siswa untuk menyesuaikan diri dengan perubahan-perubahan di lingkungan sekitarnya. Pada proses pembelajaran IPA di sekolah dasar perlu diciptakan kondisi pembelajaran yang dapat mendorong 
siswa untuk aktif dan ingin tahu. Keterlibatan siswa secara aktif dalam proses pembelajaran dimaksudkan agar siswa dapat menemukan sendiri konsep-konsep IPA melalui pengalaman belajar.

Pelaksanaan IPA di sekolah dasar pada kenyataannya tidak sesuai dengan apa yang diharapkan selama ini. Hal ini terlihat dari rendahnya hasil belajar IPA siswa. Rendahnya hasil belajar IPA siswa ini dibuktikan dengan hasil dari Programme for International Student Assessment (PISA) 2015 yang menyatakan bahwa Indonesia berada pada peringkat 62 dari 70 negara. Selain itu, berdasarkan hasil dari TIMSS \& PIRLS International Study Center dinyatakan bahwa prestasi IPA negara Indonesia berada pada peringkat 44 dari 47 negara.

Berdasarkan hasil wawancara yang dilakukan pada tanggal 5 Januari 2017 dengan beberapa guru mata pelajaran IPA kelas V SD Gugus V Kecamatan Melaya, didapatkan hasil bahwa hasil belajar siswa pada mata pelajaran IPA masih tergolong rendah. Hal ini terjadi karena, siswa masih mengalami kesulitan dalam memahami dan menguasai materi IPA. Selain itu, dalam pembelajaran guru jarang menggunakan model pembelajaran inovatif dan media pembelajaran yang sesuai diterapkan dalam pembelajaran IPA. Ini terjadi karena guru kurang memahami penggunaan model pembelajaran inovatif dan media pembelajaran yang sesuai dalam proses pembelajaran. Hal inilah yang menyebabkan siswa merasa jenuh selama proses pembelajaran, sehingga berakibat pada rendahnya hasil belajar siswa.

Ketika dilakukan observasi pada tanggal 5 dan 6 Januari 2017 di SD yang ada di Gugus V Kecamatan Melaya, Kabupaten Jembrana rendahnya hasil belajar IPA disebabkan oleh beberapa hal yaitu: (1) siswa kesulitan dalam memahami materi pembelajaran, (2) siswa pasif dalam proses pembelajaran, (3) kurangnya minat belajar peserta didik, (4) siswa yang lebih pintar tidak mau menjadi tutor bagi temannya yang berkemampuan lebih rendah, (5) jarangnya penggunaan model dan media pembelajaran yang inovatif oleh guru dalam proses pembelajaran di kelas.

Dari pernyataan di atas, terlihat jelas bahwa dalam pembelajaran IPA siswa kesulitan dalam memahami materi pembelajaran dan dalam proses pembelajaran yang berlangsung kurang melibatkan siswa secara aktif. Mengingat hal tersebut, tidaklah heran jika hal ini akan berdampak terhadap hasil belajar siswa yang cenderung rendah. Pernyataan tersebut didukung oleh hasil pencatatan dokumen tentang rincian KKM dan rata-rata nilai ulangan umum IPA siswa, yang dapat dilihat pada tabel 1 di bawah ini.

Tabel 1. Rata-rata Nilai UAS Siswa Kelas V SD Gugus V Kecamatan Melaya Kabupaten Jembrana Tahun Pelajaran 2016/2017

\begin{tabular}{|c|c|c|c|c|c|c|}
\hline \multirow[b]{2}{*}{ No } & \multirow[b]{2}{*}{ Sekolah } & \multirow[b]{2}{*}{$\begin{array}{l}\text { Jumlah } \\
\text { Siswa }\end{array}$} & \multirow[b]{2}{*}{ KKM } & \multicolumn{2}{|c|}{ Keterangan Siswa } & \multirow{2}{*}{$\begin{array}{l}\text { Rata- } \\
\text { Rata } \\
\text { Nilai } \\
\text { UAS }\end{array}$} \\
\hline & & & & Tuntas & $\begin{array}{c}\text { Tidak } \\
\text { Tuntas }\end{array}$ & \\
\hline 1 & SD Negeri 1 Tukadaya & 26 & 70 & 12 & 14 & 67,2 \\
\hline 2 & SD Negeri 2 Tukadaya & 25 & 65 & 14 & 11 & 63,1 \\
\hline 3 & SD Negeri 3 Tukadaya & 11 & 65 & 5 & 6 & 62,2 \\
\hline 4 & SD Negeri 4 Tukadaya & 18 & 65 & 8 & 10 & 64,2 \\
\hline 5 & SD Negeri 5 Tukadaya & 12 & 65 & 5 & 7 & 63,4 \\
\hline \multirow[t]{2}{*}{6} & SD Negeri 3 Tuwed & 28 & 67 & 8 & 20 & 64,3 \\
\hline & Jumlah & 120 & & 52 & 68 & \\
\hline
\end{tabular}

(Sumber: Daftar Nilai SD di Gugus V Kecamatan Melaya, 2017)

Salah satu solusi yang dapat dilakukan adalah dengan menerapkan model pembelajaran kooperatif dalam proses pembelajarannya. Model pembelajaran kooperatif adalah suatu model pembelajaran yang dalam kegiatan pembelajarannya siswa dituntut untuk terlibat secara aktif, sehingga siswa dapat menemukan sendiri konsepkonsep belajar melalui pengalaman belajar. Salah satu model pembelajaran kooperatif yang dapat digunakan, yaitu model pembelajaran kooperatif tipe talking stick.

Model pembelajaran kooperatif adalah suatu model pembelajaran yang dalam kegiatan pembelajarannya siswa dituntut untuk terlibat secara aktif, sehingga siswa dapat menemukan sendiri konsep-konsep belajar melalui pengalaman belajar. Salah satu model pembelajaran kooperatif yang dapat digunakan, yaitu model pembelajaran kooperatif tipe talking stick. Model pembelajaran kooperatif tipe talking stick merupakan model pembelajaran yang menuntut siswa untuk berani berbicara dan mengemukakan pendapatnya. Dalam penggunaan model pembelajaran kooperatif tipe talking stick siswa dituntut untuk siap menjawab pertanyaan atau mengemukakan pendapat tanpa terlebih dahulu ditunjuk atau mengajukan diri, namun berdasarkan pemberhentian tongkat yang digilir pada setiap siswa. Hal ini dimaksudkan untuk meminimalisir terjadinya penguasaan kelas oleh siswa yang pintar. Melalui penggunaan model pembelajaran kooperatif tipe talking stick dalam pembelajaran dapat menjadikan siswa terbiasa menjawab pertanyaan dan mengemukakan pendapatnya, sehingga siswa menjadi aktif. Hal ini sejalan dengan pendapat Suprijono (2009) yang menyatakan bahwa model pembelajaran talking stick mendorong peserta didik untuk berani mengemukakan pendapatnya. Penggunaan 
model pembelajaran kooperatif tipe Talking Stick dalam pembelajaran juga dapat menimbulkan rasa senang pada diri siswa karena model ini bersifat permainan yang menyenangkan.

Selain dengan penggunaan model pembelajaran kooperatif tipe talking stick untuk meningkatkan keaktifan siswa, dapat juga dibantu dengan pengunaan media dalam pembelajaran yang dapat menarik perhatian siswa dan juga untuk mengurangi peran guru dalam pembelajaran. Salah satu media yang dapat digunakan, yaitu media question box. Media question box adalah "media sederhana yang berbentuk kotak yang didalamnya berisi sejumlah pertanyaan yang akan diambil tiap-tiap anggota kelompok secara acak" (Purwantini, 2013). Media question box ini digunakan untuk membantu proses pembelajaran dalam penggunaan model pembelajaran kooperatif tipe talking stick. Dengan menggunakan media question box ini guru tidak lagi membacakan pertanyaan yang akan diberikan kepada siswa tetapi siswa langsung mengambil pertanyaan pada media question box, sehingga dapat memudahkan peran guru dalam proses pembelajaran.

Berdasarkan uraian tersebut maka akan diujicobakan model pembelajaran kooperatif tipe Talking Stick dengan judul penelitian "Pengaruh Model Pembelajaran Kooperatif Tipe Talking Stik Berbantuan Media Question Box terhadap Hasil Belajar IPA Kelas V SD Gugus V Kecamatan Melaya Kabupaten Jembrana Tahun Pelajaran 2016/2017”. Diharapkan dengan menggunakan model pembelajaran ini proses pembelajaran menjadi menyenangkan dan siswa menjadi aktif serta dapat mencapai hasil belajar yang optimal.

\section{Metode Penelitian}

Penelitian ini dilaksanakan di kelas V SD Gugus V Kecamatan Melaya Kabupaten Jembrana. Penelitian ini merupakan jenis penelitian eksperimen semu (quasi eksperimen) karena tidak semua variabel yang muncul dalam kondisi eksperimen dapat diukur dan dikontrol secara ketat. Penelitian ini menggunakan rancangan "Nonequivalen Post Test Only Control Group Design", yang secara prosedural mengikuti pola seperti yang ditunjukkan pada $\quad$ Tabel 22 berikut

Tabel 2. Rancangan Penelitian

\begin{tabular}{ccc}
\hline Kelas & Treatment & Post-test \\
\hline Eksperimen & $\mathrm{X}_{1}$ & $\mathrm{O}_{1}$ \\
\hline Kontrol & - & $\mathrm{O}_{2}$ \\
\hline
\end{tabular}

(Sumber: dimodifikasi dari Sugiyono, 2015: 116)

Populasi dalam penelitian ini adalah kelompok siswa kelas V SD Gugus V Kecamatan Melaya. Jumlah SD keseluruhannya sebanyak 6 SD dengan 6 kelas dan jumlah seluruh siswa kelas V adalah 120 siswa.

Sampel merupakan bagian dari populasi yang sudah dianggap mewakili seluruh populasi yang diambil dengan menggunakan teknik tertentu. Teknik pengambilan sampel yang digunakan dalam penelitian ini, yaitu teknik random sampling dengan menggunakan sistem undian. Dalam penelitian ini penentuan sampel diawali dengan melakukan uji kesetaraan terhadap seluruh SD yang ada di Gugus V Kecamatan Melaya Kabupaten Jembrana yang dihitung berdasarkan nilai Ulangan Akhir Semester, dengan menggunakan rumus Analisis Varians Satu Jalur (ANAVA A). Dari uji ANAVA yang telah dilakukan diketahui bahwa kemampuan siswa kelas V SD Gugus V Kecamatan Melaya Kabupaten Jembrana tahun pelajaran 2016/2017 pada mata pelajaran IPA dinyatakan setara. Setelah memperoleh hasil perhitungan uji ANAVA A keenam SD tersebut dirandom untuk menentukan kelompok eksperimen dan kempok sampel, dua kelas yang muncul langsung dipilih sebagai kelompok sampel. Kemudian, kedua kelas yang terpilih sebagai sampel di undi untuk menentukan kelompok eksperimen dan kelompok kontrol. Adapun sampel yang terpilih, yaitu SD Negeri 1 Tukadaya sebagai kelompok eksperimen dan SD Negeri 2 Tukadaya sebagai kelompok kontrol.

Pengumpulan data dalam penelitian ini menggunakan metode tes. Tes dalam penelitian ini digunakan untuk mengetahui hasil belajar IPA siswa kelas V SD Gugus V Kecamatan Melaya Kabupaten Jembrana Tahun Pelajaran 2016/2017. Instrumen yang digunakan berupa tes pilihan ganda (objektif) dengan empat alternatif jawaban. Tes ini bertujuan untuk mengukur seberapa jauh tingkat pemahaman siswa terhadap pelajaran IPA yang telah mereka peroleh. Adapun penyusunan instrumen tes hasil belajar IPA ini berpedoman pada kisi-kisi tes yang telah disusun berdasarkan kompetensi yang dicapai.

Sebelum digunakan instrumen tes hasil belajar IPA ini melalui tahap pengujian instrumen penelitian. Uji coba instrumen penelitian dilakukan untuk mendapat gambaran secara empirik apakah instrumen hasil belajar layak digunakan sebagai instrumen penelitian. Instrumen penelitian yang digunakan dalam penelitian ini terlebih dahulu dilakukan penilaian pakar (judges) sebelum ditetapkan sebagai instrumen penelitian. Selanjutnnya, dilakukan uji coba istrumen dengan jumlah responden sebanyak 65 orang. Kemudian dilakukan uji validitas tes, uji reliabilitas tes, daya beda tes, dan tingkat taraf kesukaran tes. Dari hasil uji instrumen yang telah dilakukan didapatkan 30 butir soal IPA yang dapat digunakan untuk post-test dari total 40 butir soal yang diujicobakan. 
Metode analisis data dalam penelitian ini menggunakan metode analisis statistik deskriptif dan statistik inferensial. Analisis deskriptif dilakukan untuk mengetahui tinggi rendahnya kualitas dari dua variabel yaitu model pembelajaran talking stick berbantuan question box dan hasil belajar siswa. Untuk menentukan tinggi rendahnya kualitas variabel-variabel tersebut, nilai rata-rata (mean) tiap-tiap variabel dikonversikan dengan menggunakan kriteria rata-rata ideal dan standar deviasi.

Untuk mengetahui perbedaan yang signifikan pada hasil belajar IPA antara kelompok siswa yang dibelajarkan dengan menggunakan model pembelajaran kooperatif tipe talking stick berbantuan media question box dan kelompok siswa yang dibelajarkan bukan dengan model pembelajaran kooperatif tipe talking stick berbantuan media question box pada siswa kelas V SD Gugus V Kecamatan Melaya Kabupaten Jembrana tahun ajaran 2016/2017, dilakukan uji hipotesis dengan menggunakan uji-t. Sebelum dilakukan pengujian hipotesis penelitian, terlebih dahulu dilakukan pengujian prasyarat yang meliputi dua bagian yaitu, uji normalitas dan uji homogenitas.

\section{Hasil Dan Pembahasan}

Berdasarkan hasil analisis deskriptif data hasil belajar IPA kelompok eksperimen yang dibelajarkan dengan menggunakan model pembelajaran kooperatif tipe talking stick berbantuan media question box diperoleh rata-rata hasil belajar IPA sebesar 22,57. Sedangkan, hasil analisis deskriptif data hasil belajar IPA kelompok eksperimen yang dibelajarkan bukan dengan model pembelajaran kooperatif tipe talking stick berbantuan media question box diperoleh rata-rata hasil belajar IPA sebesar 15,64. Data tersebut menunjukkan bahwa rata-rata hasil belajar IPA kelompok eksperimen lebih besar dari rata-rata hasil belajar kelompok kontrol.

Untuk mengetahui kualitas variabel hasil belajar IPA kelompok eksperimen dan kelompok kontrol, skor rata-rata hasil belajar siswa dikonversikan menggunakan kriteria rata-rata ideal $\left(\mathrm{M}_{1}\right)$ dan standar deviasi ideal $\left(\mathrm{SD}_{\mathrm{i}}\right)$. Berdasarkan hasil konversi diketahui bahwa rata-rata hasil belajar IPA siswa kelompok eksperimen yang dibelajarkan dengan menggunakan model pembelajaran kooperatif tipe talking stick berbantuan media question box berada pada kategori sangat tinggi. Sedangkan, rata-rata hasil belajar IPA siswa kelompok kontrol yang dibelajarkan bukan dengan menggunakan model pembelajaran kooperatif tipe talking stick berbantuan media question box berada pada kategori sedang.

Sebelum melakukan pengujian hipotesis, terlebih dahulu dilakukan pengujian asumsi data hasil penelitian yang meliputi (1) uji normalitas sebaran data dan (2) uji homogenitas varians. Berdasarkan hasil uji normalitas diketahui bahwa $\chi^{2}$ hitung hasil belajar IPA kelompok eksperimen dan kelompok kontrol lebih kecil daripada $\chi^{2}$ tabel ( $\chi^{2}$ hitung $<\chi^{2}$ tabel), sehingga data skor hasil belajar IPA kelompok eksperimen dan kelompok kontrol berdistribusi normal. Sedangkan, berdasarkan uji homogenitas diketahui $\mathrm{F}_{\text {hitung }}<\mathrm{F}_{\text {tabel }}$ hal ini berarti $\mathrm{H}_{0}$ diterima dan varians data hasil belajar IPA kelompok eksperimen dan kontrol homogen.

Untuk mengetahui pengaruh model pembelajaran kooperatif tipe talking stick berbantuan media question box terhadap hasil belajar IPA siswa, maka dilakukan pengujian terhadap hipotesis nol $\left(\mathrm{H}_{0}\right)$. Pengujian hipotesis tersebut menggunakan uji-t sampel independent (tidak berkorelasi) dengan rumus polled varians. Kriteria pengujian adalah tolak $\mathrm{H}_{0}$ jika $\mathrm{t}_{\text {hitung }}>\mathrm{t}_{\text {tabel }}$, dimana $\mathrm{t}_{\text {tabel }}$ diperoleh dari tabel distribusi $t$ pada taraf signifikansi 5\% dengan derajat kebebasan $\mathrm{db}=\mathrm{n} 1+\mathrm{n} 2-2$. Rangkuman hasil analisis uji-t dapat dilihat pada Tabel 3 berikut ini.

Tabel 3. Rangkuman Hasil Uji-t

\begin{tabular}{|c|c|c|c|c|c|c|}
\hline Kelompok & $\mathrm{N}$ & $\mathrm{Db}$ & Mean $(\bar{x})$ & $\mathrm{s}^{2}$ & $\mathrm{t}_{\text {hitung }}$ & $\mathrm{t}_{\text {tabel }}$ \\
\hline Eksperimen & 26 & \multirow{2}{*}{49} & 22,57 & 16,443 & \multirow{2}{*}{6,3} & \multirow[t]{2}{*}{2,009} \\
\hline Kontrol & 25 & & 15,64 & 14,584 & & \\
\hline
\end{tabular}

Berdasarkan Tabel 3, dapat diketahui bahwa $t_{\text {hitung }}>\mathrm{t}_{\text {tabel }}$, maka $\mathrm{H}_{0}$ ditolak dan $\mathrm{H}_{1}$ diterima. Artinya, terdapat perbedaan yang signifikan hasil belajar IPA antara kelompok siswa yang dibelajarkan dengan menggunakan model pembelajaran kooperatif tipe talking stick berbantuan media question box dan kelompok siswa yang dibelajarkan bukan dengan model pembelajaran kooperatif tipe talking stick berbantuan media question box pada siswa kelas V SD Gugus V Kecamatan Melaya Kabupaten Jembrana tahun ajaran 2016/2017.

Berdasarkan deskripsi data hasil penelitian, hasil belajar kelompok siswa yang mengikuti pembelajaran dengan model pembelajaran kooperatif tipe talking stick berbantuan media question box lebih tinggi dibandingkan dengan kelompok siswa yang mengikuti pembelajaran bukan dengan model pembelajaran kooperatif tipe talking stick berbantuan media question box. Hal tersebut disebabkan karena adanya perbedaan situasi belajar antara kelompok eksperimen dan kelompok kontrol. 
Model pembelajaran kooperatif tipe talking stick berbantuan media question box merupakan salah satu dari model pembelajaran kooperatif. Hal ini diperkuat oleh pernyataan Kurniasih \& Sani (2015), yakni model pembelajaran talking stick merupakan satu dari sekian banyak model pembelajaran kooperatif. Model pembelajaran kooperatif tipe talking stick berbantuan media question box memberikan kesempatan kepada siswa untuk belajar atau berdiskusi dalam kelompok belajar. Di dalam kelompok, siswa dapat bertukar pikiran mengenai materi pembelajaran yang belum dipahaminya dan siswa dapat membantu satu sama lain untuk memecahkan masalah yang diberikan oleh guru. Dengan pembentukan kelompok, siswa bisa belajar bagaimana cara bersosialisasi dengan teman sekelompoknya dan belajar untuk berani mengemukakan pendapatnya di dalam kelompok. Isjoni (2010) menyatakan bahwa dengan menerapkan model pembelajaran kooperatif dapat memotivasi siswa untuk berani mengamukakan pendapatnya, menghargai pendapat teman, dan saling memberikan pendapat (sharing ideas). Temuan selama penelitian di kelompok eksperimen yang merupakan akibat dari penggunaan model pembelajaran kooperatif tipe talking stick berbantuan media question box dapat dipaparkan sebagai berikut.

Pertama, siswa aktif pada saat proses pembelajaran. Hal ini terjadi karena dalam penggunaan model pembelajaran kooperatif tipe talking stick setiap siswa didorong untuk berani mengemukakan pendapat dengan menggunakan media tongkat. Dalam hal ini setiap siswa yang mendapatkan giliran memegang tongkat memiliki hak yang sama untuk mengeluarkan gagasan atau pendapatnya, sehingga siswa menjadi aktif dalam proses pembelajaran karena tidak hanya siswa yang memiliki kemampuan lebih saja yang bisa menjawab pertanyaan atau berpendapat. Hal ini sesuai dengan pendapat Suprijono (2009) yang menyatakan bahwa model pembelajaran talking stick mendorong peserta didik untuk berani mengemukakan pendapatnya. Selain itu, Lisdayanti (2014) juga menyatakan bahwa model pembelajaran talking stick merupakan pembelajaran yang inovatif dan kooperatif dimana menggunakan sebuah tongkat sebagai alat bantu pembelajaran yang membuat siswa lebih aktif dalam proses pembelajaran dimana siswa lebih berani mengungkapkan pendapatnya sendiri.

Kedua, siswa tertantang dalam mengikuti pembelajaran. Hal ini karena dalam kegiatan talking stick berbantuan media question box siswa tidak mengetahui kapan ia akan mendapat giliran untuk menjawab pertanyaan. Hal inilah yang memacu siswa menjadi lebih giat mempelajari materi karena dalam model ini siswa tidak tahu kapan ia akan mendapatkan giliran memegang tongkat, sehingga siswa merasa antusias dan tertantang untuk bisa menjawab setiap pertanyaan yang didapat. Pada saat penelitian, terlihat siswa sangat rajin membaca buku atau bertanya jawab dengan teman-temannya untuk memahami materi pelajaran, hal ini karena siswa berkeinginan untuk bisa menjawab setiap soal yang didapat. Hal ini diperkuat oleh pernyataan yang dikemukakan Ruhimat, dkk (2011), yakni apabila dalam situasi belajar siswa menghadapi suatu tujuan yang harus dicapai dan dalam mencapa tujuan tersebut siswa dihadapkan kepada sejumlah hambatan/tantangan maka timbullah motif untuk mengatasi tantangan tersebut dengan mempelajari bahan belajar. Dengan kata lain, jika bahan belajar dikemas dalam suatu kondisi yang menantang, seperti mengandung masalah yang perlu dipecahkan maka siswa akan tertantang untuk mempelajarinya.

Keempat, suasana belajar menjadi lebih menyenangkan. Hal ini terjadi karena dalam kegiatan talking stick berbantuan media question box terdapat unsur permainan sehingga pembelajaran tidak menjadi membosankan. Hal ini sesuai dengan perkembangan peserta didik yang masih berada pada usia bermain. Dalam proses pembelajaran terlihat bahwa siswa tampak antusias dan bersemangat mengikuti kegiatan talking stick berbantuan media question box. Hal ini diperkuat dengan pernyataan yang dikemukakan oleh Puspitawangi (2016) yakni, pembelajaran tampak menyenangkan dengan menyisipkan unsur permainan sehingga pembelajaran tidak monoton dan tidak membosankan.

Kelima, siswa termotivasi untuk terus bisa menjawab setiap pertanyaan yang di dapat. Hal ini karena dalam proses pembelajaran siswa diberikan penghargaan oleh guru yang berupa pujian dan penghargaan dari teman-temannya berupa tepuk tangan jika siswa tersebut berhasil menjawab pertanyaan yang di dapat. Dengan adanya penghargaan dapat membuat siswa merasa lebih dihargai, menimbulkan rasa bangga pada diri siswa, sehingga siswa terpacu untuk belajar lebih giat agar dapat menjawab setiap pertanyaan. Nasution, dkk (1992) menyatakan bahwa hasil belajar pada umumnya akan meningkat jika motivasi untuk belajar bertambah. Jadi, dengan pemberian motivasi kepada siswa baik itu berupa motivasi dari dalam diri maupun luar diri dapat meningkatkan hasil belajar siswa. Dengan penggunaan model pembelajaran kooperatif tipe talking stick berbantuan media question box dalam pembelajaran dapat membuat siswa menjadi aktif dan tertantang dalam belajar. Hal inilah yang menyebabkan hasil belajar siswa meningkat. Pembelajaran yang menyenangkan dan pemberian motivasi juga sangat berperan penting dalam meningkatkan hasil belajar siswa.

Proses pembelajaran yang terjadi pada kelas kontrol dengan menggunakan model pembelajaran yang bukan model pembelajaran kooperatif tipe talking stick berbantuan media question box berbeda dengan proses pembelajaran dengan menerapkan model pembelajaran kooperatif tipe talking stick berbantuan media question box. Yang dimaksud dengan bukan model pembelajaran kooperatif tipe talking stick berbantuan media question box adalah pembelajaran yang diterapkan sehari-hari oleh guru. Contoh pembelajaran yang dilakukan guru yaitu dengan tanya jawab, ceramah, penugasan, dan diskusi kelompok. Pada proses pembelajaran dengan menggunakan model pembelajaran yang bukan model pembelajaran kooperatif tipe talking stick berbantuan 
media question box minat siswa dalam mengikuti pembelajaran kurang, siswa cenderung pasif dan terkesan bosan dengan situasi pembelajaran yang seperti itu. Perbedaan situasi belajar tersebut tentunya dapat mempengaruhi hasil belajar siswa. Perbedaan situasi pembelajaran yang terjadi disebabkan oleh adanya perbedaan perlakuan pada pembelajarannya. Seperti yang sudah dijelaskan diatas, yang dimaksud dengan bukan model pembelajaran kooperatif tipe talking stick berbantuan media question box adalah pembelajaran yang diterapkan sehari-hari oleh guru. Dalam pembelajarannya, memang guru sudah membelajarkan siswa secara berkelompok. Namun, dalam kelompok tersebut kegiatan diskusi lebih di dominasi oleh siswa yang memiliki kemampuan lebih sedangkan siswa yang memiliki kemampuan kurang cenderung pasif dan hanya melihat apa yang dilakukan oleh siswa yang berkemampuan lebih sehingga hal ini menyebabkan penguasaan materi dalam kelompok tidak merata, hanya siswa yang berkemampuan lebih yang mengerti dengan apa yang dikerjakan dalam diskusi kelompok. Selain itu, dalam diskusi kelompok siswa yang berkemampuan kurang hanya melakukan tugas sesuai apa yang diperintahkan oleh siswa yang memiliki kemampuan lebih. Dalam penyampaian hasil diskusi kelompok juga hanya disampaikan oleh siswa yang memiliki kemampuan yang lebih, siswa yang memiliki kemampuan kurang tidak berani menyampaikan hasil diskusi kelompok karena mereka tidak mengerti dengan apa yang dikerjakan dalam diskusi. Hal tersebut dapat membuat siswa yang memiliki kemampuan kurang tidak mempunyai kemampuan untuk mengemukakan pendapatnya di depan kelas dan materi pembelajaran kurang dikuasai oleh siswa. Selain itu, dari hasil tes evaluasi juga dapat dilihat bahwa hanya siswa yang berkemampuan lebih yang memperoleh nilai yang baik, sedangkan siswa yang berkemampuan kurang masih berada di bahwa rata-rata. Dengan penggunaan model pembelajaran yang seperti ini dapat membuat pemahaman materi oleh siswa menjadi kurang baik, pemahaman yang diperoleh cenderung bersifat sementara, siswa kurang berani untuk mengemukakan pendapatnya, dan proses pembelajaran cenderung membosankan. Hal tersebut berdampak pada rendahnya hasil belajar IPA siswa.

Hasil temuan di atas didukung oleh temuan dalam penelitian Puspitawangi (2016) yang menunjukkan bahwa model pembelajaran kooperatif tipe talking stick berpengaruh positif terhadap hasil belajar siswa dibandingkan dengan pembelajaran yang menggunakan bukan model pembelajaran kooperatif tipe talking stick. Hal ini disebabkan karena model pembelajaran kooperatif tipe talking stick memiliki tahapan yang berbeda dan dalam proses pembelajarannya siswa terlibat secara langsung. Pembelajaran tampak menyenangkan dengan menyisipkan unsur permainan sehingga pembelajaran tidak monoton dan tidak membosankan. Selain itu siswa lebih giat menjawab pertanyaan atau mengemukakan pendapat berdasarkan pemberhentian tongkat. Sehingga, hal ini berdampak pada hasil belajar siswa yang dibelajarkan dengan model pembelajaran kooperatif tipe talking stick lebih tinggi dibandingkan dengan pembelajaran yang menggunakan bukan model pembelajaran kooperatif tipe talking stick. Relevansi penelitian ini adalah sama-sama meneliti tentang hasil belajar pada ranah kognitif dengan menerapkan model pembelajaran kooperatif tipe talking stick.

\section{Simpulan Dan Saran}

Berdasarkan hasil penelitian dan pembahasan dapat disimpulkan bahwa pertama, kualitas hasil belajar IPA kelompok eksperimen yang dibelajarkan dengan menggunakan model pembelajaran kooperatif tipe talking stick berbantuan media question box berada pada kategori sangat tinggi. Kedua, kualitas hasil belajar IPA siswa kelompok kontrol yang dibelajarkan bukan dengan menggunakan model pembelajaran kooperatif tipe talking stick berbantuan media question box berada pada kategori sedang. Ketiga, hasil belajar kelompok siswa yang mengikuti pembelajaran dengan model pembelajaran kooperatif tipe talking stick berbantuan media question box lebih tinggi dibandingkan dengan kelompok siswa yang mengikuti pembelajaran bukan dengan model pembelajaran kooperatif tipe talking stick berbantuan media question box. Hal ini berarti terdapat perbedaan yang signifikan hasil belajar IPA antara kelompok siswa yang dibelajarkan dengan model pembelajaran kooperatif tipe talking stick berbantuan media question box dan dan kelompok siswa yang dibelajarkan bukan dengan model pembelajaran kooperatif tipe talking stick berbantuan media question box. Adanya perbedaan yang signifikan menunjukkan bahwa penerapan model pembelajaran kooperatif tipe talking stick berbantuan media question box berpengaruh positif terhadap hasil belajar kognitif IPA siswa.

Saran yang dapat disampaikan berdasarkan penelitian yang telah dilakukan adalah sebagai berikut. Pertama, bagi seluruh siswa kelas V SD Gugus V Kecamatan Melaya Kabupaten Jembrana agar selalu giat belajar, memperhatikan pelajaran, serta berpartisipasi aktif dalam proses pembelajaran sehingga dapat memcapai hasil belajar yang optimal. Kedua, bagi guru dapat melanjutkan pelaksanaan pembelajaran dengan model pembelajaran kooperatif tipe talking stick berbantuan media question box melalui berbagai modifikasi agar sesuai dengan materi dan peserta didik. Ketiga, bagi Kepala Sekolah dapat menjadikan hasil penelitian ini sebagai dasar kebijakan untuk membina guru mengembangkan model pembelajaran yang lebih inovatif. Keempat, bagi peneliti lain hasil penelitian ini dapat menjadi informasi berharga bagi para peneliti lain dalam bidang pendidikan (model pembelajaran) ditingkat pendidikan dasar untuk meneliti variabel lain yang diduga memiliki kontribusi kuat terhadap konsep-konsep dan teori-teori tentang model pembelajaran. 


\section{Daftar Pustaka}

IEA. 2015. International Science Achievement. Tersedia pada: http://timss2015.org/timss-2015/science/studentachievement/. Diakses pada tanggal 8 Februari 2017.

Isjoni. 2010. Cooperative Learning Mengembangkan Kemampuan Belajar Kelompok. Bandung: Alfabeta.

Kurniasih, Imas \& Sani Berlin. 2015. Ragam Pengembangan Model Pembelajaran untuk Peningkatan Profesionalitas Guru. Jakarta: Kata Pena.

Lisdayanti, Ni Putu. 2014. "Pengaruh Model Pembelajaran Kooperatif Talking Stick Berbantuan Media Gambar Terhadap Hasil Belajar IPA Siswa Kelas V SD Gugus 4 Baturiti”. Jurnal Mimbar PGSD: Vol. 2 No. 1. Tersedia pada http://ejournal.undiksha.ac.id/index.php/JJPGSD (diakses tanggal 16 Januari 2017).

Nasution, Noehi., dkk. 1992. Psikologi Pendidikan. Jakarta: Departemen Pendidikan Tinggi dan Kebudayaan Proyek Pembina Tenaga Kependidikan Pendidikan Tinggi.

OECD. 2016. Programme for International Student Assessment (PISA) Result from PISA 2015. Tersedia pada: http://www.oecd.org/pisa/. Diakses pada tanggal 8 Februari 2016.

Puspitawangi, K. Rai. 2016. "Pengaruh Model Pembelajaran Kooperatif Tipe Talking Stick Berbantuan Media Audio Terhadap Hasil Belajar IPS Siswa”. Jurnal Mimbar PGSD: Vol. 4 No. 1. Tersedia pada http://ejournal.undiksha.ac.id/index.php/JJPGSD (diakses tanggal 16 Januari 2017).

Ruhimat, Toto., dkk. Kurikulum \& Pembelajaran. Jakarta: PT Raja Grafindo Persada.

Sugiyono. 2015. Metode Penelitian Pendidikan. Bandung: Alfabeta.

Suprijono, Agus. 2009. Cooperative Learning Teori dan Aplikasi PAIKEM. Yogyakarta: Pustaka Belajar.

Undang-Undang Republik Indonesia No. 20 Tahun 2003 Tentang Sistem Pendidikan Nasional. 2003. Departemen Pendidikan Nasional. 